\title{
Revolution and politics in Venezuela and Curaçao, $1795-1800$
}

Ramón Aizpurua

Economic and social relations between Venezuela and Curaçao in the late eighteenth century were dense, complex, and varied in content. ${ }^{1}$ From the time the Dutch settled on the small island in 1634 and particularly after their authority was recognized in 1650 , Curaçaoans and Venezuelans enjoyed regular commercial relations. Once the island became a free port in 1674, this relationship attained such importance that at times it might have been thought that Venezuela's ties to the Dutch Republic were tighter than those with Spain. This developed into a symbiotic, mutually beneficial relationship, particularly throughout the eighteenth century. Venezuelan products and produce were daily fare at Curaçaoan tables. A large portion of the harvest from Tierra Firme found its way onto the foreign market through Curaçaoan traders, who set sail daily in their vessels to ply the waters of the Caribbean, finding in what was then known as the coast of Caracas, and especially the coast of Coro, their principal trading partner (Aizpurua 1993, 2004a; Klooster 1998). This dense trade relationship was accompanied by continuous, commonplace interactions among the people who gave it life. It was not unusual to find Curaçaoan merchants and mariners in Venezuelan waters, nor unusual to find Venezuelan mariners and merchants in Curaçao. Slaves who fled the island throughout the eighteenth century found a relative but real land of liberty in Venezuela, especially in Coro, where probably more than a thousand slaves landed, fleeing slavery and the abuse of their island masters (Aizpurua 2002, 2004b, 2008; Rupert 2006, 2008).

1 Translated from Spanish by Susan Greenblatt. This paper was written in part with support from the research and development project Culturas indígenas y afroamericanas: Procesos identitarios en la construcción de la ciudadanía. HAR2009-09766 (HIST sub-programme). 
However, these relations, both commercial and human, were not free of tension, especially in a time as politically conflictive as the eighteenth century, during which Spain and the Dutch Republic found themselves, actively or passively, mixed up in the dispute between England and France to rule the colonial world, at the end with a new contender in the ring, the United States of America. The Dutch Republic and Spain, and particularly Venezuela and Curaçao, went from being irreconcilable opponents to being brothers of fortune and misfortune, or at least it appeared that way in high political spheres (Aizpurua 1993, Arauz 1984, Klooster 1998). Often, political events in Curaçao would have immediate repercussions in Venezuela, and, likewise, political turmoil in Venezuela had immediate consequences in Curaçao.

When the Caribbean started boiling over from the events set in motion in the European colonies by the French and Haitian revolutions, the course of political relations between Curaçao and Venezuela took an unclear and unpredictable turn. Three major social and political conflicts occurred in Venezuela during the period from 1795 to 1800 , events that had ramifications on the island, and in turn appear to have had connections or ties to other events and individuals from Curaçao. Moreover, on the island, for its part, two social and political conflicts transpired that appear to have been related to events and individuals from Venezuela. Contrary to what might be expected, while all of this turmoil was related to the revolutionary changes in the Caribbean, institutions rather than individuals played a vital role.

This contribution does not offer a detailed study of the political and social conflicts of both colonies, but rather attempts to discover the often hidden connections between the two colonies, and to disentangle what role either France or England, or both, had in them.

THE CORO SLAVE REVOLT, $1795^{2}$

On Sunday night, 10 May 1795, an uprising of slaves and free blacks began at El Socorro plantation, in the mountains of Coro, which soon spread to other plantations in the area, around a small town called Curimagua. All that night and the following day, the upris-

2 Venezuelan historiography has been generous in studies regarding 'Chirinos' Insurrection', as it is called, but this generosity has not been accompanied by serious analysis up until quite recently, apart from the pioneering but elementary work of Pedro Manuel Arcaya (Arcaya 1910). Aizpurua 1985 contains a general and critical overview. 
ing grew as more local people joined in, mostly people of colour as well as some Indians from the region. Several plantations and houses were looted and burned, and their owners and whoever else was found there were killed or wounded. The morning of 12 May, a large party of rebels approached the town of Coro, down the mountains, where, following several skirmishes, they were defeated by troops mustered by the town's authorities and inhabitants. In the pursuit of the rebels, many were summarily 'executed' after statements were hurriedly taken from them, if taken at all. Those who managed to escape the official repression were pursued for some time, especially the leader, José Leonardo Chirinos, who gave his name to the uprising and who was finally caught in mid-August and executed a few days later.

The number of dead, whether among the white highland landowners, their families or sharecroppers, or among the slaves and people of colour who joined the insurrection, was not only larger than in the few previous cases of slave revolts known up until that time, but also showed an unusual level of violence. The deaths and brutality of the uprising, the maxims quoted by the rebels, and the interpretation that the local people and the town's authorities soon gave to the event, led it to be identified with the events in Saint-Domingue, as soon as news of the uprising started reaching Coro, throughout the day on 11 May. The authorities immediately thought that the rebels were invoking the Haitian Revolution and therefore sought a connection between the humble highland slaves and the French ideas of liberty, equality, and fraternity. Such a connection was soon found and, with it, another leader of the revolt, José Caridad González.

José Leonardo Chirinos (JLCh) was a zambo from the mountains, son of a slave and an Indian woman, and therefore free, married to a slave, and therefore, the father of slaves. Rumour had it that he enjoyed the admiration of his wife's owner, José Tellería. On his plantation, Macanillas, he worked a small plot of land, known in Venezuela and Curaçao as a conuco. Apparently esteemed and trusted by Tellería, he had accompanied him on several business trips, probably to Curaçao, and especially to Saint-Domingue. It is said that during these trips, and inspired by conversations with Tellería or those that he would overhear between him and other whites, JLCh adopted the ideas of the French Republic and the Haitian Revolution, which he subsequently shared with his peers, most of them mountain slaves.

José Caridad González (JCG) had a distinctly different beginning; he was a runaway slave from Curaçao who had obtained his freedom after fleeing the island and making it to Coro, as had a great number of marooned slaves before him. Most of these run- 
aways, probably over a thousand during the eighteenth century, ended up settling on lands granted them by the Crown, on the northern slopes of the Coro mountains, overlooking the town of Coro, in a village known as Santa María de la Chapa. Following several lengthy lawsuits with local landholders, the village was moved to Macuquita, a few kilometres to the east along the same side of the mountains. However, a good number of the runaway slaves from Curaçao had settled in the town of Coro, forming a neighbourhood that at the time was called Guinea, now known as Curazaíto. This community of runaway slaves, now freedmen, had several leaders, and it appears that JCG was the last to join the struggle for pre-eminence and prestige among these leaders, who enjoyed, in addition, the highest ranks in the militia of free blacks of Coro, composed of both free Creole blacks and free blacks from Curaçao, commonly known as luangos.

In the years leading up to the May 1795 insurrection, JCG had sued twice, once over ownership of the mountain lands, another time for the formation of a militia of blacks, but now exclusively of luangos, to be commanded by himself, which it appears he did not fully achieve. Thus he clashed with two totally distinct social classes - landowners who were well connected to the Coro town government, and black luangos who, up until then, had been leaders of their community. His ties to Curaçao, a failed trip to the Court in Madrid demanding ownership of the land in the mountains (Chapa-Macuquita), and a trip to Caracas to defend his militia proposal to the Caracas authorities, have led to speculation about his enlightened ideas and about how his failure to accomplish much had fanned his frustration. What is certain is that while JCG and his people reported to the Coro authorities at the first call to arms upon learning the news of the uprising in the mountains, the town's authorities and 'chieftains' were suspicious of their offer of aid as militiamen. Instead of giving them the arms they were requesting to defend the town, they were arrested and locked up in the home of the governor's lieutenant, Manuel Ramírez de Valderráin. Several days later, while being transferred to jail, three of them, JCG and two of his comrades, were 'killed while attempting to escape'.

The rest of the luango community was drawn into the affair in rather confusing ways. At the time, a fortification on the coast was under construction a few kilometres to the northeast of the port of Coro in a small settlement called Vela de Coro. Luangos worked here in two weekly crews - the mountain luangos and the town luangos. When the connection between JCG and JLCh was 'established', the workers were surreptitiously and deceitfully called into town, where they were detained, though not charged, pending fur- 
ther investigation. In time, some sixty of them were sent to Puerto Cabello, to serve on the ships of the Spanish Armada that were in the harbour. Curiously, the former luango community leaders, José Domingo Rojas and Domingo Rojas (no family relation), were not among those arrested.

Following protracted inquiries, the colonial authorities ruled out any connection between the luango community and the insurrection in the mountains, although some of them may have participated in it and had been executed in the first days of the revolt. Likewise, JCG and his comrades were exonerated, leading in the end, and following several years of 'banishment' on the Armada's ships, to the luangos return to Coro and the mountains. ${ }^{3}$

A few months later the slave revolt of Curaçao erupted. This made the Coro authorities wonder and perhaps worry about connections, but a possible relationship between the two events was never proved. ${ }^{4}$

\section{THE REPUBLICAN CONSPIRACY OF LA GUAIRA AND CARACAS, $1797^{5}$}

In July 1797, a conspiracy was uncovered in Caracas, which had its roots in the port of La Guaira in a variegated circle of white bureaucrats, whites involved in maritime trade, soldiers from the regular troops, and mulatto militiamen, primarily from the port itself. The plan had been devised by a retired colonel from the regular troops, Manuel Gual, who lived on a small plantation in the interior of the province of Venezuela, and a Spanish prisoner, Juan Bautista Picornell, at that time imprisoned in the forts at La Guaira while awaiting dispatch to his final destination, Veracruz. Picornell had been sentenced to life imprisonment for his republican conspiracy in Madrid, known as the San Blas conspiracy, discovered in May 1795,

3 For everything related to this insurrection, I have used the official file of decrees drawn up by the Royal Audiencia of Caracas, in the Archivo General de Indias (AGI), Caracas 426, of the Documentos de la Insurrección 1994-97, as well as Archivo Libertador (Caracas), copied at the Bolivarium Archive, Universidad Simón Bolívar, Caracas, legajos 74, 145, 164, and 165.

4 Governor Carbonell received news from Curaçao by September 1795. In fact, a commissioner who had gone to the island in search of stores and provisions for the royal fleet, Antonio Hernández de Orta, would suggest a ban on the traffic of trade ships to the island, which Carbonell decreed in due course. As the governor did not think that this measure was sufficient, he also prohibited the entry of blacks, even those who were truly recently arrived slaves. See Archivo General de Indias [AGI], Estado 65, No. 19, folios 1-1v.

5 As in the preceding case, much has been written but little analysed on the matter, except in the equally pioneering case of Casto Fulgencio López (López 1955). For a detailed treatment, see Aizpurua 2007. 
and with him in the jails of La Guaira were several of his closest collaborators, in particular Juan Cortés de Campomanes.

Thanks to the lax state of the ruling colonial authority in La Guaira, the principal port of the Venezuelan colony, the detainees who had arrived in Venezuela between late 1796 and early 1797 were able to mingle with their jailers and the local people as soon as they arrived. The cells where they were confined soon became salons that drew people from all social strata of La Guaira, especially second-tier whites, merchants and treasury authorities, and frontline military men and soldiers, mulatto militiamen and artisans. Little by little, they hatched a plan for an uprising that, inspired by the speeches and written proclamations of Picornell, sought to do away with the monarchy and establish a multiracial republic.

As the detainees attempted to bring more local discontents into the conspiracy, the colonial authorities caught wind of the plan and swiftly and efficiently eradicated the movement. They conducted a sweeping investigation that brought to light both the conspiracy and the social fabric out of which it was being stitched; a feeble fabric that limited the chances of success, in particular due to the mistrust between the whites and mulattoes. Curiously, the clearest and most resolute among the accused were the Creole mulatto militiamen and artisans as well as the low-ranking soldiers, all Spaniards. The white conspirators, radical when planning the conspiracy and the republic, were reticent about their participation once they were exposed as conspirators. One part of the white group was peninsular bureaucrats and traders living in La Guaira, who quickly dissociated themselves from the mulatto militiamen and Creole 'troublemakers'. The other part was comprised of midranking active and retired military men, meeting in La Guaira to make modifications in the port's fortification system, although there were also some who came from a kind of local Creole white middle class. Two of the latter group lent their names to the conspiracy - Manuel Gual and José María España. They, for different reasons, not only backed down when the plan was discovered but also escaped from the province, and were the only two who, initially, dodged colonial justice.

The conspiracy for a republic included taking full control of the province of Venezuela, getting people from other cities in the region involved in it, and governing it by the motto of the French Revolution - liberty, equality, and fraternity. In the ideas set down in the written plans, obtained by the colonial authorities, equality of the 'races' was confusingly formulated, and among the conspirators' ideas was that of making contact with Caribbean experiments along these lines, especially that of Guadeloupe, where Victor 
Hugues was said to have peacefully incorporated 'people of colour' into the new republic.

The entire plan fell apart, and, just as Picornell and Campomanes had done before in late June 1797, Gual and España escaped to Curaçao one month later, in late July, where they made contact with local residents and French agents on the island, perhaps with the idea of amplifying their original plan with any aid that the Curaçaoans and French might provide. Once on the island, they soon reported to the governor of the island, Johann Rudolf Lauffer. They lodged in the house or inn of Felipe Piar, ${ }^{6}$ son of a mulatto Curaçaoan woman and a Canarian captain who travelled to the island. His brother was Manuel Piar, who was to have an important role in the first years of the so-called Venezuelan War of Independence, but ended up executed in 1817 at the orders of Simón Bolívar himself, following a murky trial in which racial problems may have been lurking.

When a commissioner, José Rafael Oberto, arrived along with a privateer, Captain Pedro Castillo, with the mission of transporting them back to La Guaira under arrest, it seems that Gual and España sought protection with the French merchant Jean Baptiste Tierce. Lauffer attempted to find and arrest them in order to turn them over to Commissioner Oberto - that at least is what he told the Caracas government. The fugitives moved into Tierce's house, where they even met with Castillo. Soon after, Castillo, Oberto and José Obediente, the person commissioned by Lauffer to help Oberto apprehend Gual and España, were chased and harassed by mobs of people who followed them everywhere, insulting them with '...there goes the aristocrat who comes to take away the revolutionaries, and the traitor who helps them...'7

Aided by Tierce, Gual and España had began to recruit volunteers for the expedition they were planning with the aim of first taking La Guaira and next assaulting Caracas to overthrow the Spanish authorities. From among the varied population of Curaçao - locals,

6 Isabel Gómez, mother of the Piar brothers and a midwife by profession, was living in La Guaira when she was deported to Curaçao after it was detected that the fugitives were staying in the house of one of her children. See Archivo de la Academia Nacional de la Historia de Venezuela, Civiles:12-4750-4.

7 These were the words of Pedro Castillo, as reported to the Caracas authorities. The event was such common knowledge that even Tierce himself informed Governor Carbonell of it on 30-8-1797: AGI, Audiencia de Caracas 432, pieza 79, folios 70v-71v. In the Spanish documentation, his name always appears as Tierce de Cadet, or simply Cadet, and he was considered to be a consul or representative of the French government of Saint-Domingue in Curaçao, but it appears that he was never recognized as such by the Curaçaoan authorities or by the French Directory; he worked as a maritime agent. 
Frenchmen, and Spaniards - many of whom were probably crew members on Curaçaoan ships or French corsairs, they managed to 'enlist' a large number, some 400 people, among whom 100 pesos were distributed daily to keep them committed to the project; some informants spoke of local Jewish support. Some of these conspirators, for example, the Frenchman Boissere, went along with the refugees from La Guaira, supposedly to learn the expedition's intent. In a long letter to Governor Pedro Carbonell disclosing the conspiracy, Boissere maintained that the French were the true captains of the project, and that its ultimate aim was to seize the riches of the Royal Treasury in Caracas, which they thought might hold over 20,000 pesos. $^{8}$

However, as the 'persecution' intensified, in November 1797 Gual and España decide to travel to Jacmel in Saint-Domingue in search of more help, men and money for their invasion plan. The very day they were to leave for Jacmel, Picornell arrived from Guadeloupe with a letter of introduction from the commissioner Victor Hugues, sent to make contact with Tierce to enlist his help to mount an expedition that was to invade La Guaira. Tierce received Picornell at his home and an invasion plan was hatched, for which España travelled to Guadeloupe to confirm the aid that, apparently, Victor Hugues had offered. The trip was unfruitful because the French commissioner was convinced that the pretensions of Picornell, whom he had met with in July of that year, as well as those of Gual and España, were based on fantasy - Picornell believed that as soon as they arrived in La Guaira, the people would rise up with them. España returned to Curaçao with empty hands, now accompanied by Cortés de Campomanes, who had initially remained on the French island. On the return voyage, they stopped at the Swedish colony of St. Barthélemy, where España won the support of several of the island's merchants, from whom he obtained an offer of aid, something he claimed to have obtained also in Guadeloupe, directly from merchants on the French island. ${ }^{9}$

Upon their arrival in Curaçao late in 1798, Cortés de Campomanes went ashore, but España did not because he learned that Lauffer had issued a warrant for his arrest. He decided to leave for SaintDomingue, via Aruba, travelling on the ship of Juan Pedro Maduro,

8 AGI, Audiencia de Caracas 435, documentos sueltos, folios 1-16. This also appears in a letter sent to Governor Pedro Carbonell by Monsieur Boissiere, AGI, Caracas 432, pieza 81, folios 1-15v. This case serves to show the diverse references to the affair. José María España called him Laboysere in his statements (see following note).

9 All this information comes from AGI, Caracas 433, pieza 91, folios 70v-82, second statement from José María España, 3-5-1799. 
a free coloured merchant and mariner, and friend of Tierce. While Maduro was busy buying mules to take back to the French island, Gual arrived in Aruba too on a ship belonging to Pedro Brión, for whom Tierce had worked and whom the Frenchman considered a close friend. They finally left for Jacmel, where they stayed for several days. There, Gual decided to speak with the English authorities of Martinique, travelled there, and subsequently went to Trinidad (recently conquered by the English), where he tried to sell his idea of invading Venezuela and making it a republic. ${ }^{10}$

España stayed in Jacmel, working with several French merchants, but was uncertain about his future. He travelled first to the Danish colony of St. Thomas and then to St. Barthélemy, seeking the help of his brother-in-law Kiruan, with whom he stayed for a time on the first island and with whom he moved to the second, helping him manage several plantations. When everything seemed to indicate that this would be the end of the adventure, he decided to go to La Guaira to look for his family. He travelled there via Trinidad, where he tried to connect with Gual. However, he did not like how the island's governor, Thomas Picton, handled the situation and in early 1799 decided to sail on to La Guaira. There, España hid in his own house until his presence was exposed by one of his ex-slaves, who had been sold in La Guaira after all of España's property had been seized in 1797. Arrested in late April 1799, long statements were taken from him, after which he was sentenced to death and executed immediately, on 6 May $1799 .{ }^{11}$

Gual's fate was no better, despite having made contact with Francisco de Miranda, who at the time was attempting in London to mount an expedition to invade Venezuela with support from the English government. He was trailed by several spies and died in Trinidad, apparently poisoned, in late 1800.

In hindsight, Gual, España, Picornell, and Cortés seem to have attempted to sell their plan for revolution to both the French, in Guadeloupe to Commissioner Victor Hugues and in Curaçao to Tierce, and to the English, in Martinique to Admiral Ralph Abercromby and in Trinidad to Governor Picton, but without much success. Perhaps indeed they would have obtained economic support from merchants in Guadeloupe, St. Thomas, St. Barthélemy, and even Curaçao, who would have viewed this aid as a sort of 'investment' in the future, expecting profits in the event the rich Spanish colony became an independent republic with their friends at the helm. For their part, the French and English governments were

10 Great Britain occupied Martinique from 1794 to 1802.

11 AGI, Caracas 433, pieza 91, folios 70v-82. 
involved in their own conflict and probably saw in these 'imaginative' Venezuelan revolutionaries possible allies for their own plans, whether to capture Curaçao, still an island of economic importance in the thick of the privateering business, or with a view to the economic and logistical importance and potential that Venezuela had, particularly after the Saint-Domingue insurrection.

It also appears that these men were 'pawns' in the intrigues on the island itself, where economic and personal interests most likely were clashing behind political and ideological loyalties. Otherwise it is hard to understand the odd behaviour of Tierce and Lauffer toward the Venezuelan fugitives, first inciting the expedition but leaving them on their own, or of hiding them from the Caracas authorities yet pursuing them. Lauffer, as well as Tierce and General Urbain Devaux, in their various letters to Carbonell and his successor Guevara y Vasconcelos, presented themselves as devoted, selfless allies of the Spanish Crown, requesting their aid for the trying times on the island in 1799, but keeping their distance from each other Lauffer in one corner, and Tierce and Devaux in another. However, José María España declared before the Caracas authorities that he thought Tierce was following orders from Lauffer in supporting the plan for the naval expedition to La Guaira.

THE CONSPIRACY OF FRENCH CORSAIRS AND CREOLE MULATTOES

IN MARACAIBO, 1799

Two years after the conspiracy of La Guaira, an even more tangled case of socio-political conflict occurred in Venezuela, this time in another important port, Maracaibo, in the colony's west. Once again, people of colour, French corsairs, and Curaçaoan seamen and logistics joined forces in a failed attempt at establishing a republic on Venezuelan soil. ${ }^{12}$ Of the three cases presented here, this is the most obscure because it is still not clear who the instigator of the plan was. Instead, it appears to be one of those situations in which the sum of the circumstances obscures the essence of the affair and the fragility of the venture.

12 I have not included individual references in my synopsis, which I have prepared using the documentation about the conspiracy in six piezas de autos issued by the Royal Audiencia of Caracas, and in the Archivo General de la Nación (AGN), Diversos LXXIV, folios 242-354v, in the AGN, Caracas, reproduced in their entirety in the CD La sublevación intentada por los corsarios franceses de Puerto Principe, 1799-1800 (documentary compilation), annexed to the Master's thesis in history submitted by Ángel Manzanillo, in Caracas, Universidad Central de Venezuela, 2000 (CDSMbo). 
On the night of 6 May 1799, three ships reached port in Maracaibo, two corsairs from Saint-Domingue, the Bruto and the Patrulla, and their British prize, the Arlequín. The first two belonged to the Gaspar brothers, natives of Port-au-Prince, with one, Jean-Baptiste, at the helm of the first, and the other, Auguste, commanding the other. They had left Port-au-Prince bound for St. Thomas, but a storm blew them to the coast of Guaranao, where they seized the English ship, which they soon boarded and added to their group. Due to the poor shape they were all in, and their lack of victuals, they decided to seek refuge and aid in Maracaibo, and to legalize their prize.

Once in port, the boats were visited by the Maracaibo authorities, and with the circumstances and cargo explained, the Arlequin was declared good prize. For some twelve days, the crews of the privateer ships lived the routine port life, disembarking to eat and drink, or receiving local curiosity seekers on board. Meanwhile, the authorities had designated several individuals to mediate and monitor their stay.

Nevertheless, something out of the ordinary must have happened. Soon, the two Gaspar brothers, aided by one of their subordinates, José Romano, second captain of the Bruto, a native and resident of the island of St. Thomas, began talking with Francisco Javier Pirela, second lieutenant of the First Company of Disciplined Mulatto Militias of Maracaibo, a 35-year-old widower from the town, and a tailor by profession. Though it is difficult to know who took the initiative, their conversations soon came around to the idea of taking the town for the purpose of declaring a republic. Some offered their men, arms, and cannon, along with money, another offered the militia or those he could assemble, and they decided to rise up on the night of 19 May, a Sunday.

However, as on other occasions, the uprising did not break out. One of the first men whom Pirela attempted to win over, Tomás de Ochoa, first corporal of the First Veteran Company of Maracaibo, informed the governor, Fernando Miyares y Gonzáles, who that night organized an assault on the three ships, taking their crews prisoner, including the Arlequin's sailors, whose cannon had been loaded for an attack on the city.

The investigation did not take long and, even though those who gave statements claimed their innocence and blamed others, saying that it was 'the rest of them' who were trying to incite the uprising, some clear ideas can be extracted. The first is that once more fantasy was fanning the flames of the insurrectional plans, especially when in the heat of argument and alcohol allies came along offering assistance that was hard to guarantee. Additionally, it is probable that Pirela and Romano, who acted as interpreter between Pirela and the corsair captains, fell under the spell and imagined 
the formation of a republic in the city as a fait accompli, which would soon be linked to an uprising in the city of Cartagena. As in the previous case, the plan included arresting the authorities and murdering them, taking over the city, subjugating the population, especially those who did not identify with the insurrection, seizing the funds in the Royal Treasury, which they thought amounted to 20,000 pesos, and appointing authorities from among the people of colour.

The conspirators also thought of turning to Curaçao in search of more people and armaments, according to Pirela, who said that Romano had told him that 'he would send to Curaçao for more people, armaments and munitions of war to sustain and establish themselves in this country'. ${ }^{13}$ Some of the privateers were Curaçaoans, as were some of the crewmembers of the English prize. ${ }^{14}$ Although it seemed clear that there was a plan for an uprising, and the Gaspar brothers, Romano, Pirela, and several other locals and sailors were found guilty, there is no more information available. However, the case of Maracaibo does seem to demonstrate a pattern in the behaviour of Saint-Domingue privateers and of Guadeloupean and French republican officials in European colonies with coloured populations, as will be seen below.

VENEZUELAN AUTHORITIES AND POLITICAL CONFLICTS IN CURAÇAO, $1799^{-1} 8$ OO $^{15}$

Meanwhile in Curaçao, other events were taking place that were related to the French and Haitian revolutions and to the strug-

13 CDSMbo, Pieza 5, folios 544-545 (folio 545), statement from Francisco Javier Pirela, 28-6-1799.

14 Most prominent were Jacob Gómez, native and resident of the island of Curaçao, second captain of the Bruto, who stated he was hired by the corsairs to take them to the island; Juan Jeres, boatswain of the Bruto; and Silvestre Castro, native of Curaçao, aged 44 years, and pilot for the French corsairs, who had taken the position in Port-au-Prince, who in their declarations presented themselves as having been forced by circumstances to participate in the uprising plan, but never as leaders; for their part, from the prize were the Curaçaoans Diego Cristiano, a black sailor of 20 years, Julián Francisco, mulatto, sailor of some 17 years, who spoke good Spanish, and Juan González de Castro, a sailor of colour, aged 44 years, who stated having been excluded from the uprising plan and having been kept as prisoners by the corsairs until the day of the planned uprising, although the second one, Julian Francisco, clarified that one of the Gaspar brothers had offered money 'so that he would not reveal him nor declare anything that would be to his detriment in the anticipated uprising'. ECMbo, Pieza 4, folios 427v-430 (folio 429v), declaration of Julián Francisco, sailor, mulatto, native and resident of Curaçao. Maracaibo, 1-6-1799.

15 On the case studied here, see also Felice 1973:415-443, who used similar sources, but from other document collections. 
gles of groups of colour throughout the Caribbean. By November 1796, following the conflict that pitted Orangists against Patriots in Curaçao and led to the replacement of the island's governor Johannes de Veer by Jacob Beaujon, Dutch officials and sailors who were not supporters of the Batavian Republic began to arrive in Venezuela. This happened, for example, to Frederik Harrias, drum major of the troops, and Abraham de Pon, a sailor on one of the frigates of war of the new republic, forced to abandon the island by its governor. ${ }^{16}$

The authorities of Caracas closely followed the conflict that had broken out on the island and informed the authorities in Spain, who, in turn, instructed their ambassador in the Batavian Republic, José de Anduaga, to attempt to detain Tierce for the purpose of finishing the investigation regarding the plans of Gual and España. ${ }^{17}$ The governor of Caracas had already informed the Spanish authorities about this event, including a report from the lieutenant of Coro, Emilio Boggiero, who said that the advocates of the planned uprising had been Devaux and Tierce, and that they had their principal ally in naval officer Albert Kikkert, but that Lauffer had concealed the alliance. Also on the island at the time was a Jew named Isaac Sasportas, ${ }^{18}$ sent by Toussaint Louverture, although Boggiero indicated that he had not taken part in this particular conspiracy. The plan had been uncovered by the new French consul on the island, Joubert, who rejected the offer made by Devaux to join the plot, informing Lauffer of the matter instead.

A few days later, on 11 September 1799, an emissary of the military leader of the Haitian mulattoes, André Rigaud, arrived on the island, bringing the news that both Devaux and Sasportas had been sent by his rival Toussaint to incite the island. In addition, the Brigade Commander and Major General of Jacmel, named Bobbay (according to Boggiero's report) arrived, fleeing from Toussaint; he was attempting to sail for Paris to inform the Directory of the outrageous situation in Saint-Domingue. Boggiero also said that an old acquaintance from La Guaira had arrived on the island, the French physician Pierre Canibens, brother-in-law of José María España, and whose detention by Lauffer and later escape appears

16 AGI, Estado 65, No. 57, 'Información de llegada de Curazao de militares leales al príncipe holandés', 11-10-1796. The case is studied in this volume by Karwan Fatah Black.

17 AGI, Estado 71, No. 4.

18 At that time, nephew of José Obediente, lieutenant of the National Guard of Curaçao, interpreter and confidant of the governor of Caracas, first Pedro Carbonell and later Manuel Guevara y Vasconcelos. 
to have been behind the allegations made by Devaux and Tierce of 'insults' made in Curaçao to French citizens. ${ }^{19}$

Boggiero warned the Spanish authorities of the instability of Curaçao:

This revolutionary endeavour, which is the fourth that has been discovered since the current tribulations of the French colonies, has been, it appears, calmed down, but as the inclination of that population is known, composed almost entirely of mulattoes and blacks, freedmen and slaves, who aspire so to equality and liberty, there is no doubt that it will have a hidden ferment that some day will come to realize its intent. ${ }^{20}$

Besides the report from lieutenant Boggiero, who received fresh news in Coro from the island thanks to the daily contacts with Curaçao, the governor had an extensive epistolary relationship with the island's authorities, among whom figured Lauffer, a governor temporarily allied with the Spaniards. He also corresponded with Devaux, the local agent on the island of a nation allied with the Spanish Crown. This meant that the Caracas governor constantly kept a suspicious eye on the conflicts that had arisen on Curaçao. This was a dispute between allies, which for its part entailed possible greater conflicts among the perennial British enemy with its thirst to conquer Tierra Firme, revolutionary France and the emerging new republic in Hispaniola.

Devaux sent at least four letters to the governors of Caracas, first Pedro Carbonell and later Manuel Guevara y Vasconcelos. He acted as an agent in Curaçao for handling the prizes that French corsairs, or those from Saint-Domingue and Guadeloupe, took in the Caribbean, which they would bring to the island where they would rapidly deal with the legal cases resulting from the seizures. As such, he had complained to the governor about conflicts between Venezuelan authorities and French corsairs, being particularly interested in the case of the Gaspar brothers, who had been detained in Maracaibo some months earlier, accused of seditious plans. On 30 July, Devaux wrote to the governor of Caracas in defence of the Gaspar

19 AGI, Estado 714 (1a), folios 1-2v. Pierre Canibens, brother-in-law of José María España by marriage to his sister Joaquina, had arrived in Curaçao from Bermuda, where he had ended up after the ship which was being sent under detention to Spain was taken as a prize by English privateers. Together with him, it seems, was the other brother-in-law of España through his wife, Domingo Sánchez, who worked as an amanuensis on the island. See AGI, Caracas 433, pieza 91, folios 1v-10v, statement from José María España, 30-4-1799.

20 AGI, Caracas 433, pieza 91, folio $2 \mathrm{v}$. 
brothers, ${ }^{21}$ highlighting what would be the version of the corsairs. He explained that after the letters of marque that they had enjoyed had been taken away from them, they devoted themselves to trade, but kept their ships armed 'to defend themselves in the event of being attacked'. ${ }^{22}$ About this affair, he pressured governor Guevara in a letter sent on 2 August 1799 by telling him that 'several villains and Pirates have abused the French flag, but the French Republic is not involved at all in the vile deeds that are committed in its name; it only knows goodness and noble deeds, such are its principles and its intentions: It is also good and loyal and forthright, as it is a terrible enemy, etc.' 23

In another letter, Devaux mentioned the affair of the jailing of Pierre Canibens, pointing out that he did not previously know the French physician, but that Canibens had been detained in a manner hardly consistent with international law and was going to be turned over to the Caracas authorities 'to be sacrificed, as a result of a denunciation from his brother-in-law [José María] España', which is why Devaux had contributed to his escape. ${ }^{24}$

However, Devaux had matters of more pressing concern than trying to mediate between the Gaspar brothers, or Tierce, and the Caracas authorities. Trade, both legal and illicit, between Englishmen and North Americans (who acted as their middlemen) and the Spanish colonies did appear to cause the French agent to lose sleep, and for this reason he wrote to Governor Guevara in Caracas several times telling him how and in what waters the English were smuggling. He sent copies of some new instructions that the British king had given to his commanders for the purpose of permitting a sort of 'free trade' by enemy or allied merchants with his Caribbean colonies (dated 8 March 1798, revoking and expanding those of 27 June 1797). These favoured, in particular, Spanish traders, by permitting them to land at what they called English free ports in the Caribbean: Kingston, Savannah, Montego Bay, St. Lucia, and Port Antonio on the island of Jamaica; St. George's on Granada; Roseau on Dominica; Nassau on the island of New Providence (Bahamas); and the port of St. John's in Antigua. ${ }^{25}$ However, he intelligently added another royal decree that, complaining of the procedures of the Spanish in violent and unjustified seizures of their ships,

21 AGI, Estado 67, No. 73 (1h), folios 1-1v (folio 1), Devaux to Guevara, Curaçao 30-7-1799.

22 AGI, Estado 67, No. 73 (1h), folio 1.

23 AGI, Estado 67, No. 73 (1g), folios 1-6v (folios 2-2v), Devaux to Guevara, Curaçao of 2-81799 .

24 AGI, Estado 67, No. 73 (1j), folios 1-2, Davaux to Guevara, undated.

25 AGI Estado 67, No. 73 (11), 'Instrucciones adicionales a los comandantes ingleses', 28-31798 . 
ordered reprisals be taken against Spanish ships whose crews, once seized, were to be judged by the admiralty court. ${ }^{26}$

By doing this, Devaux pretended to draw Guevara's attention to the risk entailed by the Spanish engaging in smuggling with English enemies, but it appears that deep down his interest ran in a different direction. From the very first letter that Devaux sent Guevara, on 22 June 1799, the Frenchman communicated his need to go to Caracas to take information that he could only convey in person since it involved a secret mission. Devaux said he wanted to visit the province of Venezuela accompanied by an officer, an interpreter, and an aid,,$^{27}$ which Guevara refused. ${ }^{28}$ In response to another request along the same lines, Guevara asked him to communicate the objective of his secret mission on Tierra Firme and the objective of his intended visit since, thought Guevara, each 'step that general Devaux took with me, led me involuntarily to the opinion that he was not being sincere with me, and that his entry into these provinces could be detrimental'. ${ }^{29}$

There is no further correspondence between Devaux and Guevara since around that time the plan for insurrection against Lauffer was uncovered. However, a letter from José Obediente helps us imagine what Devaux's secret mission was. This lieutenant of the Curaçaoan National Guard said that Devaux's intentions were to visit Venezuela to ask the governor to allow him to arm an English prize, the Hermione, and to launch an attack on Trinidad with the objective of recovering it with the support of Venezuelan privateers and a force of over 200 men. Obediente added that Tierce convinced Devaux that they did not have enough money to complete this secret mission, but that if they managed to incite the island to rebellion, they could do away with Lauffer. Tierce supposedly added that

we will put the Marine Commander in his place, we will form a Directory, we will get one hundred thousand pesos out of the Jews for you, we will send one hundred fifty robust men out of the country, who are just some aristocrats, we will confiscate all the Americans who we find here, and their boats, we will cut Obediente's throat, because he is a swine and protector of the tyrant Spanish government, we will cut the throats of the crown attorney and nephew of the governor, because they are very villainous and depraved men, 
we will put people of our liking in the jobs, I have some of the National Guard up my sleeve, I will return to my position as artilleryman to win over the locals, I will take the castle, and you will take the Castle of the Republic, which is the one that rules over the whole island. After this is done, you will be able to continue on to Trinidad with greater satisfaction since there you will find all the American ships, French corsairs, and riches at your disposal. ${ }^{30}$

And here Governor Lauffer in Curaçao comes into play. On 11 September 1799, he wrote Guevara describing the planned uprising by Tierce and his allies, adding that were these plans to triumph, "not only would this colony be completely destroyed, but the security of your government and the public peace of the western coast will also be exposed to the most appalling dangers'. ${ }^{31}$ Lauffer told governor Guevara that in the event the two sides clashed he would be in need of aid because of the superiority of the French forces. He calculated that only with 500 disciplined men added to his troops would he be able to counter the French. Hence, Lauffer asked Guevara to let him know if he would be willing to aid him with 500 men from his troops, explaining, 'In the event that Your Excellency is willing to grant me this entreaty, I beg of you to have them soon at my disposition in the port of La Guaira or of Cabello. In case of necessity, I will send for them with an express messenger, or if circumstances force me to go to extremes, I myself will come for them. [...] Perhaps this is the only way to save [...] this colony, the last possession of the Batavian Republic in this hemisphere, from its complete destruction, as well as to protect your government, and the Spanish possessions of the neighbouring coasts, from the danger that threatens them' ${ }^{32}$

Guevara responded eleven days later, lamenting not being able to make indiscriminate use of his troops without the express orders of his superiors on the peninsula and asking Lauffer for details on the project of Tierce and Devaux, especially with regard to the 'number that they have within the island, and their quality, especially from the military class on land or sea' ${ }^{33}$ Guevara was already

30 AGI, Estado 67, No. 73 (1u), folios 1-3 (folio 1v), José Obediente to Governor Carbonell, Curaçao, 15-9-1799. By then, the governor was no longer Pedro Carbonell but rather Manuel Guevara y Vasconcelos. Probably, in giving this information, Obediente was following instructions from Lauffer himself on the matter.

31 AGI, Estado 67, No. 73 (1r), folios 1-2 (folio 1), Governor Johann Rudolf Lauffer to Governor Guevara, Curaçao, 11-9-1799.

32 AGI, Estado 67, No. 73 (1r), folio 1v and 2.

33 AGI, Estado 67, No. 73 (1s), folios 1-2, Governor Guevara to Governor Lauffer of Curaçao, Caracas, 22-9-1799. 
aware of the expulsion of Devaux and the jailing of Tierce, which is why he was more concerned about the issue of the political and social unrest on the island and its repercussions on Tierra Firme.

Guevara also had information gathered by Spanish informants on the island commissioned by the Caracas authorities. Thus, Manuel Farfán de los Godos, who had gone there for that purpose at the request of the Regent of the Royal Audiencia, the highest legal authority of Venezuela, had already sent a report of the events on the island. ${ }^{34}$ He detailed how he had managed to infiltrate Devaux's party, finding out that Devaux had made a list of the wealthiest men on the island and of how he had gotten Commander Kikkert to join his faction, and that he had won over all the French on the island, with the approval of Tierce, to later use the jailing of Pierre Canibens as an excuse to inflame spirits over Lauffer's alleged antiFrench posture. According to Farfán's telling,

once this was achieved, they would make the aforesaid Marine Commander [Kikkert] into the interim governor, using as a motive for this entire action and its incidents that said governor [Lauffer] wanted to surrender this island to the English, and that exposed by these people, they had killed him and his confederates because of that, and then, with the course of action produced by said general and his party, he himself [Kikkert] would go to Holland to report on the happenings, gain merit, and achieve ownership of this government for the aforementioned Marine Commander, as he had contributed with the arms at his command to the felicity that the surrender of this island to the English did not take place. ${ }^{35}$

With the governor dead, along with those the French conspirators called aristocrats, and in possession of their property and money, they would divide it among the revolutionaries. Farfán reported that after learning the nature and strategy of the plan of insurrection, he spoke with Lauffer, telling him everything. ${ }^{36}$

It is impossible to ascertain whether the information provided by Farfán is reliable or if he is reproducing the comments of Lauffer or of his assistant Obediente. If it is reliable indeed, quite possibly the plan of Tierce and Devaux was not a consequence of the orders that Devaux supposedly brought with him to the island, but rather

\footnotetext{
34 AGI, Estado 6773 (1t), folios 1-2v, Manuel Farfán de los Godos to Regent López Quintana, Curaçao, 6-9-1799.

35 AGI, Estado 6773 (1t), folio 1v.

36 It seems curious that several people claim to have informed Governor Lauffer of the French plan: Obediente, Farfán, and the new French consul on the island, Jaubert.
} 
represented a reaction to the turn of events on the island, which Lauffer then interpreted to his benefit to make way for his reaction.

Guevara also received a letter sent from Puerto Cabello on 18 September, with the latest news that had come in from the island on several ships, emphasizing that among the documents seized from the conspirators a sheet of paper was found that said that Obediente's head must roll because he was a protector of the Catholics and persecutor of the French. The letter revealed that the governor of Suriname had surrendered his colony to the English after some French corsairs had arrived in port and managed to get the colony's slaves to join their camp. ${ }^{37}$

Thus, in addition, if there is truth to a conspiracy carried out by French corsairs and agents, the events in Maracaibo in May of that same year would have to be seen as part of a more general plan, however informal it may have been - not just a consequence of circumstances or happenstance - to connect the interests and proclamations of the French and Haitian corsairs in the Caribbean with the worries of the communities of various non-French colonies in the Caribbean, whether Spanish, English, or Dutch. A similar case appears to be the conspiracy that occurred in Cartagena in April 1799. Some contemporaries linked this conspiracy to the Maracaibo affair, but the Spanish authorities did not lend great weight to this interpretation. An uprising was planned for 2 April of that year, comprised of the black slaves of French officials and recently arrived black slaves who were prisoners, apparently backed by a gunnery sergeant of the black militia named Jorge Guzmán. Eight of the black men were arrested and gave confusing statements. The alleged complot was revealed by a first corporal of the mulatto volunteers, Manuel Iturén, who learned of it from a black Creole slave. The conspirators were apparently thinking of killing the whites and looting public and private property. ${ }^{38}$

As a result of this affair, the correspondence between Lauffer and Guevara increased once again, but on this occasion the issues were even more serious. Guevara learned of a new conflict on the island from the commander of Puerto Cabello, Manuel Marmión, who wrote him on 8 September 1800 saying that a schooner coming from Curaçao had just reached port and had left the island two days earlier together with twelve or thirteen Spanish ships with permission from Lauffer after he had received information from a negotiator that the French would return as enemies 'to bring

37 AGI, Estado 67 No. 73(1v), folios 1-1v (1v), Miguel Martínez to Governor Guevara, Puerto Cabello, 18-9-1799.

38 AGI, Estado 53, No. 77. The plan to capture a port city, kill the whites, and steal public and private property seems to have been the norm in these attempted rebellions. 
everything down in fire and blood'. ${ }^{39}$ Guevara also had news of the arrival on the island of a brother of Rigaud, who was fleeing SaintDomingue and might have offered his packet boat and people to the French. He also reported that the island was in the greatest confusion due to distrust of the slaves, and that the French might be successful in their intent to incite them'. ${ }^{40}$

Additionally, the lieutenant from Coro, the abovementioned Emilio Boggiero, sent a similar letter to Guevara on the same 8 September, informing him of the arrival in the port of Coro of a canoe that had returned from Curaçao, where it had gone with a letter for Lauffer. He added to what Marmión said with news of the arrival of two boats loaded with people coming from the island - women, children, and some old people - as well as the news that other Spanish ships were doing the same, leaving Curaçao bound for Puerto Cabello and La Guaira, after Lauffer had given his permission for this on 6 September. From the explanation the canoe's captain gave to Lieutenant Boggiero, it could be deduced that the French had put together ten ships from among those that had left the port and those that had arrived from Guadeloupe, and had taken the castle of Sint Michiel by deception, and that the black slaves of the estates in the area had been liberated by the French, who had taken them into their ranks. He added that such a thing frightened him since "with all the people they have in Curaçao, those that are fleeing from Guadeloupe, and those who would come from Les Cayes [in Saint-Domingue], they are in condition to work quickly and take firm hold on these coasts, from whence perhaps they shall not again leave'. ${ }^{41}$

The following day, the administrator of the Royal Treasury of Río de Tocuyo, a small coastal town between Coro and Puerto Cabello, informed Marmión that several individuals from the island had arrived in Hueque, another coastal town, saying that part of the island had been taken over by the French and that by then the island was probably in their power. With this news, Marmión informed Guevara of the affair, adding that it would be wise not to ship to the island the provisions and refreshments that he had prepared, including cattle, which he had not done for fear that such aid might fall 'into the hands of the French and English who were crisscrossing the island' ${ }^{42}$

39 AGI, Estado 67, No. 87, folios 3v-5v (folio 4), Manuel Marmión to Governor Guevara, Puerto Cabello, 08-09-1800.

40 AGI, Estado 67, No. 87, folio 5. This must be Joseph Rigaud, in custody.

41 AGI, Estado 67, No. 87 (1a), folios 6a-10v (folio 7b), Andrés Boggiero to Governor Guevara, Coro, 08-09-1800.

42 AGI, Estado 67, No. 87 (1a), folios 11v-14v (folio 13b), Manuel Marmión to Governor Guevara, Puerto Cabello, 14-09-1800. 
In addition, in another letter that same day, Marmión informed Governor Guevara that several ships had just arrived in Puerto Cabello with a considerable number of émigrés, some ninety, including several of the island's Jewish merchant families and some free mulatto women, and that he had parcelled them out among his trading acquaintances. Most belonged to the Enríquez and Del Valle clans, with several of their slaves. The widow and daughter of an old acquaintance of the Venezuelan authorities, the merchant David Morales, had also arrived. ${ }^{43}$

On an uncertain date, though it must have been close in time, news also arrived from Paraguaná, the coastal region of Venezuela nearest to Curaçao and Aruba. Several Curaçaoan families and some Frenchmen who were aboard an English schooner were not welcomed in Aruba, so the English thought of leaving them on Tierra Firme. It was known that a boat had arrived 'with nine blacks and three whites, one from San Sebastián, another from San Juan de Cruz, and one American, the latter ones armed, and according to the inquiry, they were found to be with the French'. ${ }^{44}$ All were detained except four of the blacks and they were referred to the Coro authorities. To the consternation of the city's authorities, it appears that the four fugitives, after being found and their participation in the band of Frenchmen confirmed, were walking freely about the city. ${ }^{45}$

This situation entailed an additional problem for the Venezuelan authorities: Christian charity called on them to receive the émigrés with open arms, most of them being known to the merchants of Puerto Cabello and La Guaira. However, the fact that they were Jews expelled from Spain and its empire required additional care to be taken beyond what the law required for all foreigners without naturalization papers, apart from the fact that, once more, the factions that were fighting among themselves on the island were, at the time, allies of Spain.

The affair was studied by the Royal Audiencia which, surreptitiously, decreed that the émigrés ran no additional risk on the island and therefore should be returned forthwith to Curaçao, and that no more émigrés should be accepted, who "will have to suffer [...] the

\footnotetext{
43 AGI, Estado 67, No. 87, folios $17 \mathrm{v}-20 \mathrm{v}$.

44 AGI, Caracas 486, 'Papeleta de noticias acompañando a carta del Intendente Interino de Ejército de Caracas', Caracas, 7-10-1800. On 1-9-1800 news had been sent to Coro from the town of Santa Ana, on the Paraguaná peninsula, about the arrival of 54 persons, probably comprised of French families from Curaçao, who were sent to Coro and were distributed 'among the houses of honourable citizens who would watch over and observe their conduct' as their designs were unknown (González 1997:145).

45 AGI, Caracas 486, Manuel Carrera to Francisco de Sojo, Coro, 27-9-1800.
} 
usual discomforts and losses of comparable cases, but no explicit persecution against the lives and properties of the citizens. They shall obey whoever shall ultimately be declared Ruler of the island and shall remain in their houses and possessions, as they were before, since it is not credible that a movement of this nature have as its objective robbery, pillage, and the destruction of private citizens' ${ }^{46}$ The Venezuelan authorities were to 'protect the inhabitants of these provinces from the infection that could spread through the religious and political order'. ${ }^{47}$ Guevara immediately sent a communication with the resolution of the Royal Audiencia to the highest authorities of Coro and Puerto Cabello, so that they would act accordingly. ${ }^{48}$

A trader from Puerto Cabello, José Antonio Martel, gave a detailed description of the conflict that lasted from the $3^{\text {rd }}$ to the $14^{\text {th }}$ of September to Francisco de Sojo, treasurer of the Royal Treasury in Puerto Cabello. Martel had been on a Spanish boat that could not come into port in Willemstad, but did make port in Caracasbaai on 17 September. Martel told Sojo that they had lived through eight days of combat, with neither side showing an advantage. If the governor had given permission to leave the island, it would already have been empty of 'families', but he did not because many hidden men went along with the women and children. Martel said that he had lost his house and over 2,000 pesos, and that on the island more than one million pesos had been lost. ${ }^{49}$

Martel states in his account that on 4 September, after the French had left, 'the citizens and traders spent the entire day in revelry, feasting and rejoicing, for the sake of seeing that they were free of them, without attending to any other thing except to this entertainment'. One of those who deceived the guards of the Fort Sint Michiel was a son of Pedro Brión. ${ }^{50}$ The French schooners that remained watching over the coast of Curaçao seized several ships from the coast that were coming with provisions or to engage in business. Those that could avoid the French, in general loaded with maize and bananas, disembarked in Caracasbaai, where they sold their cargo and returned to the coast. On 8 September, Lauffer sent several officials in a boat from Coro, with news of the incidents on the English frigate Nereida. On the $9^{\text {th }}$, an American schooner arrived carrying provisions. ${ }^{51}$ Mar-

\footnotetext{
46 AGI, Estado 67, No. 87, folios 21v-24v (folios 22v-23), decree of the Royal Audiencia, Caracas, 20-9-1800.

47 AGI, Estado 67, No. 87, folio 22v.

48 AGI, Estado 67, No. 87, folio 24v, circular of Governor Guevara, Caracas, 20-9-1800.

49 AGI, Caracas 486, José Antonio Martel to Francisco Sojo, Curaçao, 14-9-1800, folio 1.

50 This quite probably was Luis Brión, later Admiral of the Venezuelan navy, during the war of independence. At the time, he was working as a translator for the French.

51 AGI, Caracas 486, folios 1-4v.
} 
tel provided details not only of the daily skirmishes, but also of the actions of the English, about whom, in another letter that continues with the account of the incidents, he says

English vessels are expected all the time, and troops of the same; therefore, I believe, and ensure, that this, when it remains for the English, they will pay them much money which is why they aid in her defence; the English frigate does not forsake us and the officers come to shore as guards every day to the fort. They have taken account of all the ships that there are in port, and the governor [Lauffer] does not let any Spanish boat leave despite all insistence, nor gives license to any person, no matter how much they protest. This is how we all are, most on their ships and others outside the city, awaiting the end of this.

Even though this place is very strong, and that it is impossible that these four Frenchmen could take it, if it were not for the English commander [of the frigate Nereida], it appears to me that they would have already surrendered, but the Englishman does not consent to it and the governor is working feverishly. ${ }^{52}$

When a negotiator sent to the island by Guevara to talk to Lauffer returned from the island, the news he brought is that no one recognized the governor's authority anymore since the captain of the English frigate did not allow it, 'repeating that [Curaçao] is a possession of Great Britain'. ${ }^{53}$ To some extent, the concern of the Venezuelan authorities was already drifting away from the aftereffects of the social and regional revolts, and was focusing on the English, who, according to the interim intendant and regent of the Royal Audiencia of Caracas, would inundate the Venezuelan coastline with contraband products and seditious papers, to 'deceive and delude the vassals of Your Majesty, as they have done since the beginning of this war, and in particular since they occupied the island of Trinidad. This, disregarding the effect that could come from the threats by said captain to invade Tierra Firme with a great armed force. ${ }^{54}$

52 AGI, Caracas 486, folios 1-1v, José Antonio Martel to Francisco de Sojo, Curaçao, 19-9-1800, in which Martel brings the information up to date regarding the five days from the $15^{\text {th }}$ to the $19^{\text {th }}$ of that month, although without the diligence of the previous report.

53 AGI, Caracas 486, folios 1-1v, 'El Intendente Interino de Ejército de Caracas Remite copias de las últimas noticias que ha tenido de los sucesos de la isla de Curazao, e indica los perjuicios que pueden causar más fácilmente los enemigos que la ocupan', Caracas, 27-10-1800. The bearer of the news was Telésforo de Orea, negotiator send to Curaçao by Governor Guevara. 54 AGI, Caracas 486, folio $1 \mathrm{v}$ 


\section{CONCLUSION}

With the information that the Venezuelan authorities and, therefore, the Spanish authorities had at their disposal, the events occurring between June 1797 and September 1800 in Curaçao are difficult to understand and interpret. Tierce and Devaux are presented as two perfidious and dangerous rebels who wanted to use Venezuelan fugitives and revolutionaries for their own personal objectives of throwing Venezuela into confusion and gaining access to the colony's wealth. The history of the insurrections and conspiracies of prior years led the colonial authorities to think this way, from the dangerous Coro insurrection in 1795, to the conspiracy of La Guaira in 1797, to the fruitless projects to subvert the order in Maracaibo and Cartagena in 1799. They thought that the French, from their own possessions or from their new stronghold in Curaçao, were behind such conflicts, with the purpose of helping to spread the 'pernicious' republican and egalitarian ideas in the Spanish colonies in the Americas, and/or to support local, often non-white revolutionaries. But the authorities in Caracas also feared that the French, in the end, would seize Curaçao and, despite being allied at the moment in their common war against the English, would set foot on Tierra Firme or at least spread their revolutionary ideas, causing social and political chaos in the Spanish colonies of the Americas.

The Spanish authorities - colonial or central - had a very uncomfortable ally in the French, as much or more so than their eternal enemy Great Britain, which they distrusted not only for having taken over in 1797 the promising island of Trinidad, off of eastern Venezuela, but also for British expansionism elsewhere in the Caribbean, including now towards Curaçao, the threshold to Venezuela. The words of the commander of Puerto Cabello cannot better describe what the Venezuelan authorities were thinking when he wrote about 'the deplorable state of that colony [Curaçao], destined to be victim of the greed and ambition of the French, or to pass perhaps under the English yoke, each extreme worse than the other'. ${ }^{55}$

Seen from this perspective, the least dangerous of Spain's 'adversaries' were, in the end, the Dutch, including the Dutch regime in Curaçao. The former intimate enemy became a bit more of a friend who, even if mistrusted, was always there, sharing the present and the future. To some extent, both Governor Lauffer and Governor 
Guevara were explicit on this. But both English and French aggression upset the situation.

It is not evident that a coordinated plan existed to subvert peoples subject to the colonial connection, in political-economic and in social terms, a scheme having its origin in Haiti or in the French colonies of the Caribbean. And yet it is tempting to 'see' in the very complex conflicts sketched above a certain 'teleology', in tune with the 'nature' of the times. But questions abound. Thus the documents and information of the period, from different sources and with different perspectives, may make it difficult to accept that Tierce and Devaux were indeed seeking to bring about a 'coup d'état' in Curaçao in September 1799, privileging the manoeuvring of Governor Lauffer as decisive instead. But there is no hard evidence to corroborate either interpretation. It does seem clear though that, aside from whatever conspiracies and orders, little was needed in those days and places to ignite revolts among the 'people of colour'. After all, revolutions often do not present themselves as such immediately, but are the often unanticipated outcome of a process. And indeed, there was no inevitable outcome of the confusing objectives and actions of Tierce, Devaux, and Lauffer, to name only three of the important protagonists: not necessarily a social revolution or the surrender of the colony to an ally or enemy.

BIBLIOGRAPHY

Aizpurua, Ramón

1988 'La insurrección de los negros de la Serranía de Coro de 1795: Una revisión necesaria', Boletín de la Academia Nacional de la Historia 283:705-23.

1993 Curazao y la costa de Caracas: Introducción al estudio del contrabando de la provincia de Venezuela en tiempos de la Compañia Guipuzcoana 1730-1788. Caracas: Biblioteca de la Academia Nacional de la Historia. [Fuentes para la Historia Colonial de Venezuela no. 222.]

2002

'En busca de la libertad: Los esclavos fugados de Curazao a Coro en el siglo XVIII', in: Influencias Africanas en las culturas tradicionales de los paises andinos: Memorias, pp. 69-102. Bogotá: Dupligráficas.

2004a 'El comercio curazoleño-holandés, 1700-1756', Anuario de Estudios Bolivarianos. Caracas 10-11:11-88. 
2004b 'En torno a la aparición de un pueblo de esclavos fugados de Curazao en la Sierra de Coro en el siglo XVIII', Boletín de la Academia Nacional de la Historia [Caracas], 87-345:109-128. 'La conspiración por dentro: Un análisis de las declaraciones de la Conspiración de La Guaira de 1797', in: Gual y España, la independencia frustrada, pp. 213-344. Caracas: Fundación Polar.

2008 'Esclavitud, navegación y fugas de esclavos en el Curazao del siglo XVIII', in: Javier Laviña, Pilar García and Lola Luna (eds), Poder Local, Poder Global en América Latina, pp. 83-96. Barcelona: Universitat de Barcelona Publicacions.

Arauz Monfante, Celestino Andrés

1984 El contrabando Holandes en el Caribe durante la primera mitad del siglo XVIII. Caracas: Biblioteca de la Academia Nacional de la Historia. [Fuentes para la Historia Colonial de Venezuela 168 and 169.]

Arcaya, Pedro Manuel

1910 'La insurrección de los negros de Coro', in: Discursos de incorporación, Tomo I. Caracas: Biblioteca de la Academia Nacional de la Historia 1979.

Documentos de la insurrección

1994-97 Documentos de la insurrección de José Leonardo Chirinos. Caracas: Fundación Historia y Comunicación. Two vols.

Klooster, Wim

1994 'Subordinate but proud: Curaçao's free blacks and mulattoes in the eighteenth century', New West Indian Guide 68:283-300.

1998 Illicit riches: Dutch trade in the Caribbean, 1648-1795. Leiden: KITLV Press.

López, Casto Fulgencio

1955 Juan Picornell y la conspiración de Gual y España. Caracas: Biblioteca de la Academia Nacional de la Historia.

Rupert, Linda M.

2006

Inter-imperial trade and local identity: Curaçao in the Colonial Atlantic World. PhD thesis, Duke University, Durham.

2008 'Maritime marronage and manumission in Caribbean interimperial trade', Paper, Conference 'Atlantic emancipations', McNeil Center for Early American Studies, Philadelphia. 